\title{
SELECTION OF CRITERIA FOR COMPARATIVE EVALUATION OF HOUSE BUILDING TECHNOLOGIES
}

\author{
Antonina Yudina', Yurii Tilinin² \\ 1,2 Saint Petersburg State University of Architecture and Civil Engineering \\ Vtoraja Krasnoarmejskaja ul., 4, St. Petersburg, 190005, Russia \\ ${ }^{1}$ yudinaantonina2017@mail.ru
}

\begin{abstract}
Variety of house building technologies, involving the use of masonry materials, precast reinforced-concrete structures, formwork systems and modern construction equipment, contributed to the need to perform expert evaluation of their applicability in various construction conditions. Expert evaluation of house building technologies is based on a set of weighty criteria considering not only costs of resources but consumer appeal of apartment buildings as well.

The expert evaluation method represents a tool for comparison of technologies by means of the system of incomparable criteria such as architectural expression of facades, dwelling convenience, durability, structural strength and seismic resistance of buildings, capital intensity of technologies, labor intensity and costs of construction using the considered house building technologies.
\end{abstract}

\section{Keywords}

Residential construction, house building technology, labor intensity, capital intensity, number of floors, durability, structural strength, expert evaluation, criterion selection, weighting.

\section{Introduction}

A modern construction sector involving various developing house building technologies has formed in Saint Petersburg. Among technologies of constructing residential apartment buildings, most commonly used in Saint Petersburg, masonry (conventional), panel, cast-inplace as well as cast-in-place and precast construction can be mentioned. The construction sector of Saint Petersburg in the sphere of residential construction is represented by house-building factories manufacturing precast construction elements and construction enterprises providing cast-in-place and masonry (conventional) construction. Competition between construction enterprises in the sphere of residential construction in Saint Petersburg results mainly in reducing direct costs of resources and improving consumer appeal of construction products. However, when performing comparative evaluation of house building technologies, it is necessary to consider other equally important technological, economic and urban-planning criteria. Quantitative comparison of technologies is complicated by the need to evaluate consumer appeal of apartments, architectural expression of facades, capital expenditures for technology introduction into construction, and other incomparable criteria. Therefore, to compare technologies, the expert evaluation method using the system of criteria selected by the authors is adopted.

\section{Methods}

Selecting the system of criteria for comparative evaluation of house building technologies, the authors perform a theoretical study of technological characteristics related to construction of residential apartment buildings to obtain a complete set of criteria, and then assess the weight of each criterion with account for the data of an expert poll.

According to Rybnov E.I., Egorov A.N., Hejducki Z. and Ghadimian N.G. (2018), residential apartment buildings of Saint Petersburg are the most characteristic of technologies' development in national urban house building (especially in the period of organization and planning of production entities' activities under conditions of large-scale housing construction carried out since the middle of the 20th century).

Examining the brickwork in tenement buildings in the historical center of Saint Petersburg, Golovina S.G. and 
Sokol Yu.V. (2018) performed an analysis of structural and technological characteristics of the masonry (conventional) construction system.

Modern masonry technologies are developing based on long experience in brickwork, using new masonry materials made of porous concretes and hollow clay blocks.

An analysis of options for construction of residential apartment buildings in Saint Petersburg was conducted by Yudina A.F. and D'yachkova O.N. (2010). As a result, specifics of residential construction in the period from the second half of the 19th century to the early 20th century were revealed. The authors of the paper also provided an overview of the house building technology as a system of industrial resources used mainly to erect load-bearing structures of a construction facility.

In his paper "Labor intensity as a criterion to evaluate efficiency of technical and technological solutions", published in 2016 in the Proceedings of the 72nd Scientific Conference of professors, teachers, researchers, engineers and post-graduate students of the Saint Petersburg State University of Architecture and Civil Engineering, Likhachev V.D. analyzed labor intensity as a criterion to evaluate efficiency of technological solutions in residential construction. Costs of labor resources depend directly on the applied construction technology (Likhachev, 2016).

Allen E. and lano J. (2004) categorize construction technologies according to the methods of processing materials used in construction of a facility. Among basic construction materials used to erect load-bearing structures at a construction site, the following can be mentioned: masonry and concrete mixes, brick, small and large concrete blocks, precast reinforced-concrete structures, building bars, rolled sections and industrially manufactured steel structures. Among basic methods of processing construction materials when erecting loadbearing structures of a construction facility, masonry, reinforcement, concreting and installation can be mentioned.

In his DSc thesis "Integrated automation of processes for construction of industrial facilities out of cast-in-place reinforced concrete", Mintsaev M.Sh. (2009) broke down the comprehensive process of constructing reinforcedconcrete structures at a construction site into processes of formwork assembly and disassembly, reinforcement and concreting of building structures. Figure 1 shows the technological structure of processes for construction of a cast-in-place residential building.

Construction of a cast-in-place residential building involves reinforcement, formwork and concreting performed in sequence. During erection of foundations and walls, at first reinforcement is installed and then formwork is assembled. Installation of a cast-in-place reinforced-concrete floor starts from formwork, and then reinforcement is carried out. In their monograph "Castin-place concrete. Technological basis. Concreting in winter", Kolchedantsev L.M., Vasin A.P., Osipenkova I.G., Stupakova O.G. (2016) presented data on time of concrete setting and strength gain. In case of proper curing of hardening concrete, in approximately 12-24 hours (at temperature of approximately $20^{\circ} \mathrm{C}$ ), the formwork can be disassembled and prepared to be installed at the next section.

Usually, construction of a cast-in-place building is carried out using the flow-line method and a multi-level system for quality control of formwork, reinforcement and concreting according to the method proposed by professor Yudina A.F. (2012) in her paper "Advantages of monolithic building and some problems of its perfection".

Assembly is carried out upon erection of buildings out of precast concrete or reinforced-concrete structures. The precast construction technology significantly decreases the dependence of general construction works performed at construction sites on low winter temperatures and autumn rains. If a building is mainly constructed of castin-place elements, then the corresponding technology is called cast-in-place construction. If a building is constructed by means of assembling precast structures, then the corresponding technology is called precast construction. The technology of large-panel construction also falls into the category of precast construction of residential apartment buildings.

The superstructure of a building assembled of large precast reinforced-concrete panels is erected in the following sequence: at first, concrete panel trailers or other special-purpose vehicles deliver precast elements of a residential building to the construction site, then a construction crane installs the structural units in proper position. Installation of each precast element shall involve alignment and temporary fixing of the unit with braces, clamps and jigs.

Then electric welding of inserts in connecting points of precast structures is carried out. After anti-corrosion treatment of metal in connecting points, concreting of joints is performed. When concrete strength is gained, it is possible to start constructing the next intermediate floor. While the superstructure of a standard building is invariable, the substructures are affected by heterogeneous soil and hydro-geological conditions at the construction site.

In soft water-saturated soils of Saint Petersburg, bored piles and barrette piles, recommended by Gaydo A.N. for construction of cast-in-place foundations in his paper "Ways of improving technological solutions of construction of pile foundations of residential buildings under conditions of urban development" (2015), are considered to be the most efficient.

In Saint Petersburg, construction of foundations is preceded by shoring of excavations with the technology of slurry wall made of cast-in-place reinforced concrete or in a form of secant bored piles. Installation of bored piles and slurry wall can be classified as cast-in-place construction.

The technology of erecting the load-bearing frame of a building by assembling precast reinforced-concrete structures and constructing cast-in-place reinforcedconcrete sections is called cast-in place and precast despite the fact that precast elements prevail, as discussed in the paper "Application of exposed concrete at erection 


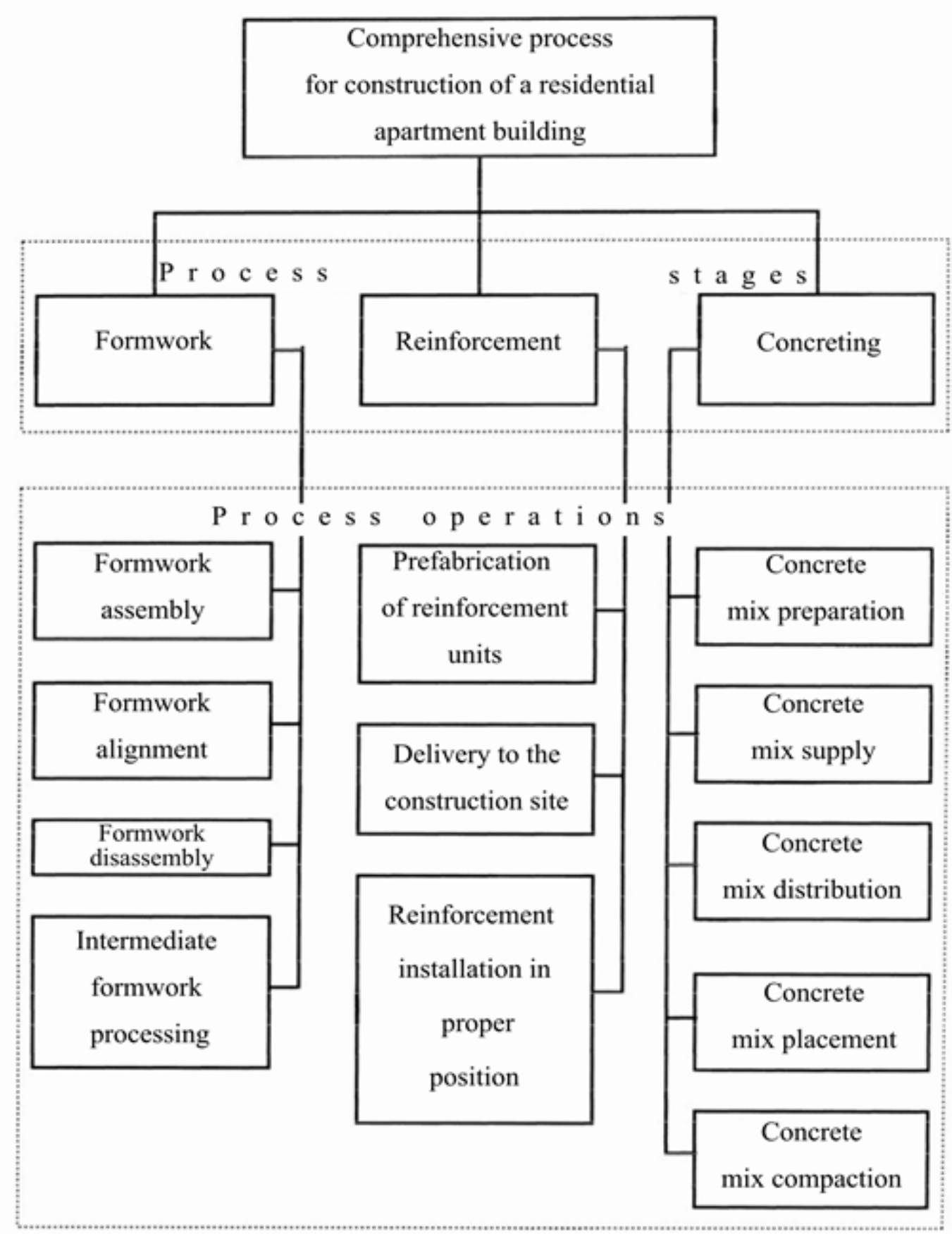

Figure 1. Technological structure of the comprehensive process for cast-in-place house building.

of monolithic buildings" by Yudina A.F. and Ponomarev M.Yu. (2016).

Construction of load-bearing walls and columns by laying brick and small blocks using sand cement or other mortar with various additives has been long used, and it is called the masonry (conventional) technology. The authors of the present paper also classify construction of brick buildings with cast-in-place or precast floors as masonry (conventional) construction.

In residential construction, modern precast buildings are usually made of panels (large panels), except for the KUB construction system and its modifications (KUB 2.5, KUB-3V) assembled of reinforced-concrete columns and panels of intermediate floors connected in a common frame with cast-in-place sections located in floor panels.
To introduce a new technology for building erection into the construction practice, investments in production facilities of construction enterprises are required. Therefore, comparing house building technologies, it is necessary to consider the capital intensity indicator, i.e. the ratio of the cost of capital used in residential construction performed according to the analyzed technology in the sphere of construction materials and sphere of construction operations to the cost of constructed residential buildings in the specific period.

Capital intensity can be evaluated using the ratio between capital expenditures and labor inputs (expenditures), i.e. specific capital expenditures per person per time unit. Besides specific capital intensity, indicators of specific labor intensity related to the house 
building technology, determined as the ratio between labor expenditures and construction volume in the specific period, are compared. Interrelation between construction volume, capital and labor expenditures in the specific period is represented by an isoquant curve (Figure 2), described in the monograph by Bazylev N.I. and Gurko S.P. "Economic theory" (Bazylev, Gurko, 2005).

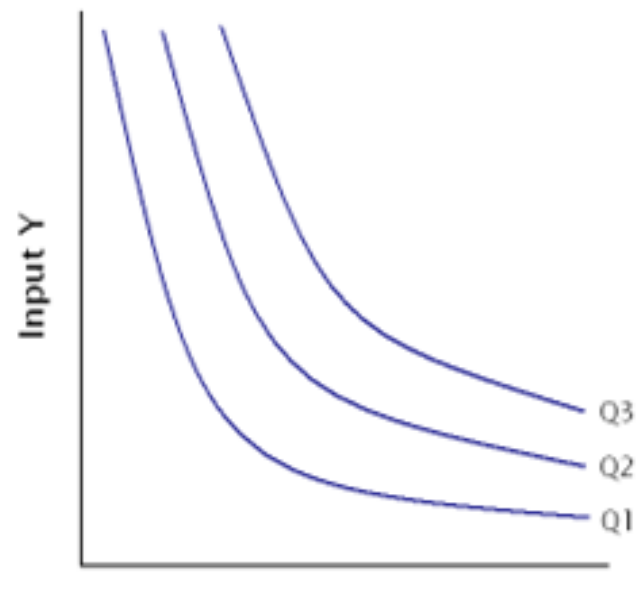

Input X

Figure 2. Isoquant curve representing interrelation between construction volume Q3 > Q2 > Q1, labor $(\mathrm{X})$ and capital $(\mathrm{Y})$ expenditures in the specific period.

The isoquant curve shows that an increase in residential construction volume due to production intensification is associated with investments in new capital-intensive house building technologies, resulting in labor efficiency increase and products' labor intensity decrease. Production expansion with no changes in labor efficiency is also associated with investments, but such expansion is extensive, i.e. it does not result in labor intensity decrease in residential construction and, therefore, does not increase product competitiveness due to cost saving.

The technology of panel or other precast construction represents a unified process for industrial manufacturing of standard sets of building structures and their assembly at construction sites, therefore, in evaluation of construction products' labor and capital intensity, costs for prefabrication at factories and assembly at construction sites are taken into account.

Total costs of resources spent to erect a construction facility are determined by the unit cost indicator, e.g. $1 \mathrm{~m}^{2}$ of the residential area. The cost of $1 \mathrm{~m}^{2}$ in a panel, castin-place, brick building amounts to approximately 38,000 , 41,000 , and 49,000 rubles, respectively.

It includes total production and construction costs related to construction of facilities according to the considered house building technology.

When comparing house building technologies, besides product costs, it is necessary to consider consumer appeal of apartments: floor level, area of rooms in an apartment, soundproofing between apartments, temperature and humidity, indoor air ventilation. Freedom in space planning in an apartment and durability of load-bearing structures in a building are essential for the developer and consumer. Opportunities of the applied technology in the sphere of architectural expression of facades are also important when accommodating a facility in an urban environment. Residential buildings located beyond the historical center of Saint Petersburg shall be high-rise, therefore, the number of floors is essential. Variety of criteria characterizing different properties of residential buildings as products of house building technologies, in relation to evaluation of not only efficiency of construction operations but capital expenditures for creation of production facilities, and consumer appeal as well, rule out direct quantitative comparison of house building technologies and force to apply the expert evaluation method using the ten-point scale for criteria measurement.

For the purposes of selecting weighty criteria for evaluation of house building technologies, criteria ranking according to their significance (weighting) is performed (Table 1).

Table 1. Ranking of criteria for evaluation of house building technologies according to their weighting.

\begin{tabular}{|c|c|c|}
\hline No. & $\begin{array}{l}\text { Criteria for evaluation of house build- } \\
\text { ing technologies }\end{array}$ & $\begin{array}{l}\text { Criterion rank- } \\
\text { ing on a ten- } \\
\text { point scale }\end{array}$ \\
\hline 1 & $\begin{array}{l}\text { Architecture, heat insulation and } \\
\text { soundproofing }\end{array}$ & \\
\hline 1.1 & Facade architectural solutions & 8 \\
\hline 1.2 & $\begin{array}{l}\text { Planning architectural solutions (free- } \\
\text { dom of planning) }\end{array}$ & 7 \\
\hline 1.3 & Reduced total area per apartment & $\begin{array}{l}6, \text { less than } \\
6.93\end{array}$ \\
\hline 1.4 & $\begin{array}{l}\text { Heat insulation (approximately equal } \\
\text { values due to insulating material) }\end{array}$ & $\begin{array}{l}5, \text { less than } \\
6.93\end{array}$ \\
\hline 1.5 & Soundproofing & 9 \\
\hline 2 & $\begin{array}{l}\text { Number of floors, structural strength, } \\
\text { durability }\end{array}$ & \\
\hline 2.1 & Number of floors & 8 \\
\hline 2.2 & $\begin{array}{l}\text { Structural strength and seismic resis- } \\
\text { tance }\end{array}$ & 10 \\
\hline 2.3 & Durability & 9 \\
\hline 3 & Cost-effectiveness, large scale & \\
\hline 3.1 & Capital intensity & 8 \\
\hline 3.2 & Prime cost & 9 \\
\hline 3.3 & Labor intensity & 9 \\
\hline 3.4 & Large scale & 7 \\
\hline 3.5 & Material intensity & $\begin{array}{l}5, \text { less than } \\
6.93\end{array}$ \\
\hline 3.6 & Industriality & $\begin{array}{l}4, \text { less than } \\
6.93\end{array}$ \\
\hline & Total points & 104 \\
\hline & Mean score & 6.93 \\
\hline
\end{tabular}


The criterion weight is calculated as per the following equation according to the method described by Gutsykova S.V. in her monograph "Expert evaluation method. Theory and practice" (2011):

$a_{i}=f\left(\frac{\sum_{k=1}^{N} a_{i k}}{N}\right)$,

where $N-$ number of experts; $a_{i}$ - number of points for the i-th criterion; $a_{i k}-$ number of points for the $i$-th criterion, given by the $k$-th expert

The mean score was calculated as the sum of points divided by the number or criteria, and amounted to 6.93 points.

When house building technologies are compared, the heat insulation criterion affects house building technology evaluation insignificantly as exterior walls of panel, castin-place, cast-in-place and precast, as well as brick buildings involve heat insulation. The reduced total area per apartment is also an insignificant criterion as the area of apartments does not depend largely on technologies. Apartments in panel, brick, cast-in-place, as well as cast-in-place and precast buildings have sufficient area exceeding regulatory values. Material intensity is indirectly taken into consideration in the prime cost, and, as an individual criterion, is insignificant.
The industriality level of an individual construction facility can be determined using the prefabrication factor. In its essence, the industriality criterion is irrelevant when technologies of precast and cast-in-place construction are compared.

\section{Results}

To perform comparative expert evaluation of house building technologies, the following criteria were selected:

1. Facade architectural solutions;

2. Planning architectural solutions;

3. Soundproofing of inter-apartment structures;

4. Permissible number of floors;

5. Structural strength and seismic resistance of a building;

6. Durability of load-bearing elements in a building

7. Technology capital intensity;

8. Cost of works;

9. Labor intensity;

10. Large scale (suitability for large-scale construction).

\section{Conclusion}

The selected criteria for comparative evaluation of existing house building technologies will be used in future studies of rational use of masonry, precast, cast-in-place, as well as cast-in-place and precast house building technologies in residential construction. 


\section{Architecture and Engineering Volume 4 Issue 1}

\section{References}

Allen, E., lano, J. (2004). Fundamentals of building construction: Materials and methods. New York: J. Wiley \& Sons.

Bazylev, N.I., Gurko, S.P. (2005). Economic theory. Minsk: Ekoperspectiva.

Gaydo, A.N. (2015). Ways of improving technological solutions of construction of pile foundations of residential buildings under conditions of urban development. Zhilishchnoe Stroitel'stvo, 9, pp. 12-15.

Golovina, S.G., Sokol, Yu.V. (2018). To the issue of studying the joint performance of building materials of enclosing structures in the former profitable houses of the historical center in St. Petersburg. Bulletin of Civil Engineers, 3 (68), pp. 112-117. DOI: 10.23968/1999-5571-2018-15-3-112-117.

Gutsykova, S.V. (2011). Expert evaluation method. Theory and practice. Moscow: Institute of Psychology of Russian Academy of Sciences.

Kolchedantsev, L.M., Vasin, A.P., Osipenkova, I.G., Stupakova, O.G. (2016). Cast-in-place concrete. Technological basis. Concreting in winter. Saint Petersburg: Lan.

Likhachev, V.D. (2016). Labor intensity as a criterion to evaluate efficiency of technical and technological solutions. In: Proceedings of the 72nd Scientific Conference of professors, teachers, researchers, engineers and post-graduate students of the Saint Petersburg State University of Architecture and Civil Engineering, part 1, pp. 108-111.

Mintsaev, M.Sh. (2009). Integrated automation of processes for construction of industrial facilities out of cast-in-place reinforced concrete. DSc Thesis in Engineering. Moscow: Moscow Automobile and Road Construction Institute.

Rybnov, E.I., Egorov, A.N., Hejducki Z., Ghadimian N.G. (2018). Organization and planning of production structures' work at large-scale housing construction. Bulletin of Civil Engineers, 3 (68), pp. 98-102. DOI: 10.23968/1999-5571-2018-15-3-98-102.

Yudina, A.F., Dyachkova, O.N. (2010). Analysis of the versions of design-construction solutions of residential multi-storey buildings (on the example of Saint Petersburg). Bulletin of Civil Engineers, 2 (23), pp. 115-122.

Yudina, A.F. (2012). Advantages of monolithic building and some problems of its perfection. Bulletin of Civil Engineers, 1 (30), pp. 154-156.

Yudina, A.F., Ponomarev, M.Yu. (2016). Application of exposed concrete at erection of monolithic buildings. Architecture and Engineering, 1 (2), pp. 73-88. DOI: 10.23968/2500-0055-2016-1-2-73-88. 